\title{
Cost Over-Run in Civil Works: A Case-Study of Engineering, Procurement and Construction (EPC) Gas Depot Construction Projects in Nigeria
}

\author{
Chukwuemeka Patrick Ogbu and Raph Ehigiator-Irughe
}

\section{ABSTRACT}

Engineering, procurement and Construction (EPC) projects in the oil and gas sector of Nigeria are under-researched. This leaves investors with little or no guide on the cost-overrun risks of oil and gas depot projects. Using the qualitative case study research technique, this study investigated cost overrun in the civil works of a petroleum products depot project in Lagos, Nigeria. The objectives were to ascertain the reasons for cost overrun and the areas of substantial cost overrun in the project. It was found that except for the cost of construction of "gantry" which was under-measured as a result of use of a wrong method of costing, the rest of the major facilities experienced cost overrun with a cumulative difference of $106 \%$. It was also discovered that the cost overruns mainly originated from design and construction activities. The study recommends the timely engagement of consultants to review the conceptual designs of contractors and monitor the activities of EPC contractors for oil and gas depot projects on behalf of clients. Such consultants should not, however, have powers to control the contractors. As much as possible, parties to EPC contracts should use standard conditions of contract that will better reflect their intentions rather than contrive bespoke conditions.

Keywords: EPC contract, contract agreement, cost overrun, oil and gas depot

Published Online: August 27, 2020

ISSN: 2684-446X

DOI: $10.24018 /$ ejgeo.2020.1.4.54

Chukwuemeka Patrick Ogbu* University of Benin, Nigeria.

(e-mail: chukwuemeka.ogbu@ ${ }^{\circledR}$ uniben.edu)

Raph Ehigiator-Irughe University of Benin, Nigeria. (e-mail: raphael.ehigiator ${ }^{@}$ uniben.edu)

*Corresponding Author

\section{INTRODUCTION}

Globally, cost overrun remains a worrisome plague of construction projects. From transport infrastructure [1], magaprojects [2] to building projects [3] construction professionals, clients, and other stakeholders have expressed dissatisfaction over the cost performance of construction work. Derakhshanalavijeh and Teixeira [4] stated that oil and gas industry projects in developing countries are not excepted from the problem of cost overrun, and such projects usually entail huge capital outlays.

Depots are necessary for warehousing large volumes of petroleum products. Scarcity of petroleum projects usually has immediate repercussions on the national economy and can compromise national security if not checked quickly. Depots help to hedge against petroleum products planned and unplanned inventory disruptions [5]. With the deregulation of the downstream section of the oil and gas industry in Nigeria on 29th September 2003, the private sector began to invest massively in the sector [6], albeit, with limited experience and research to guide their efforts. Directorate of Petroleum Resources (DPR) [7]) showed that there are 83 depots belonging to independent petroleum marketers, 24 depots belonging to major petroleum marketers and 22 depots belonging to the Nigerian National Petroleum Corporation
(NNPC)/Pipelines and Products Marketing Company (PPMC). The construction or repair of these facilities has hardly been the subject of in-depth research. The present study was necessitated by the need to understand the contract and cost management practices involved in the procurement of these facilities.

Similar to Vietnam [8], most of the depot projects in Nigeria were procured using the engineering, procurement and construction (EPC) approach. Pícha Tomek, and Löwitt [9] stated that EPC contracts are on their way to becoming the normal approach to procuring large scale infrastructural projects. Although this construction procurement method is used in many industries, its use is known to be more prominent in the oil and gas sector [10]. In spite of this, there is paucity of research literature on the use of EPC for oil and gas deport projects.

In EPC contracts, the client considers it too risky to have different design and construction 'roofs', and awards the engineering design, planning, procurement, and construction to one entity to undertake. Essentially, the contractor bears the full risk of project failure, as long as the client satisfactorily discharges his duty of honouring payment milestones. Most EPC contracts provide for a guaranteed price, and a duration at the end of which the client is handed over a fully functional completed facility [11]. The contractor 
bears an enormous task - to complete a highly risky work within a guaranteed price. However, in the quest to win contracts, contractors often become optimism biased about risks, only to fall back on claims to recover their losses. The cost overrun that results from this attitude often goes under the radar of construction management research.

Although EPC contracts are expected to provide the client with guarantees for time, quality and cost (except for clientordered variations and force majeure), the presence of risks entail that these expectations are hard to come by. Yeo and Ning [12] identified some of the challenges of EPC contracts to include phase overlaps, work fragmentation, complex organizational structure and inaccurate prediction of desired outcomes. In some cases, there are no Engineer's roles in EPC contracts, and where such exist, the Engineer wields much less powers than those granted in design-bid-build contracts. For instance, the International Federation of Consulting Engineers' (FIDIC) Silver Book (EPC/Turnkey projects) allows clients to appoint only representatives and assistants with limited powers. Sometimes, foreign EPC contractors jettison FIDIC contracts for bespoke conditions that skew EPC contracts in their favour [13]. Clients are exposed to contractor's manipulations as a result, which could lead to cost growth. This situation is worse for most indigenous depot owners in Nigeria given their relative inexperience in EPC contracts. The objectives of this study are to identify the areas of substantial cost overrun in oil and gas depot projects, and the causes of cost overrun in EPC oil and gas projects in Nigeria. This is with a view to guiding policymaking and strategy by stakeholders on EPC contracts for oil and gas depots.

\section{EPC CONTRACTS}

FIDIC [14] defines an EPC contract as any type of development

where (i) a higher degree of certainty of final price and time is required, and (ii) the Contractor takes total responsibility for the design and execution of the project, with little involvement of the Employer. Under the usual arrangements for turnkey projects, the Contractor carries out all the Engineering, Procurement and Construction (EPC): providing a fully-equipped facility, ready for operation (at the "turn of the key"). (p.9)

Schramm, Meißner, and Weidinger [15] explained that EPC contracts entail the full planning, designing, and materials and equipment supplies for the realization of the project. Picha, Tomek and Lowitt [9] opined that EPC projects also cover project management, site management, supervision, engineering, transportation and commission of the works in order to meet its full objectives. Most authors unanimously agreed that EPC contracts entail that the contractors become the single point of responsibility for the project [10], [15], [16]. In practice, this disincentivizes value management of the project by concentrating a lot of powers in the hands of the contractor. EPC contracts are typically let based on conceptual designs, which get modified prior to construction. The adequacy of such modifications and the acceptability of their cost implications often become a source of adversarial relationship between the parties.

FIDIC [17] considers the Conditions of Contract for
EPC/Turnkey Projects (Silver Book) unsuitable for use in the following circumstances:

1. If there is insufficient time or information for tenderers to scrutinise and check the Employer's Requirements or for them to carry out their designs, risk assessment studies and estimating;

2. If construction will involve substantial work underground or work in other areas which tenderers cannot inspect, unless special provisions are provided to account for unforeseen conditions or

3. If the Employer intends to supervise closely or control the Contractor's work, or to review most of the construction drawings

From the above, EPC contracts as conceived by FIDIC, should be avoided in instances where the contractor does not have the opportunity to satisfactorily analyze the riskiness of the venture prior to award, and where the Employer intends to exact significant supervisory control over the project. These ideals are flouted in some EPC projects under the guise of freedom of contract, which implies that parties are free to agree on the terms of their contract, provided that they comply with the law and public policy [18]. Such attitudes are rooted in insufficient understanding of the cost implications of the risks involved in EPC projects.

\section{A. Phases in EPC Contracts}

EPC contracts are relatively complex, and therefore require systematic approaches to the execution of the work. Cost overrun emanates from acts of omission and commission in the different stages of a project. Pham and Hadikusumo [8] grouped the major EPC procurement activities into six phases namely: preparation of investment, scope and contracting, engineering, procurement construction and start-up. Back and Moreau [19] explained the approach to involve the processes shown in Table 1. The attempts at distinguishing the stages/processes involved in EPC contracts emphasizes the significance of each stage, and the fact that errors in a stage will be carried over to the next stage. Stage-wise consideration of contract processes helps to expose risky constructability issues and aid their containment. In this study, the stages in which the factors that led to cost overrun occurred were categorized in accordance with the suggestions of Back and Moreau [19]. Carefully, following these phases/stages should ensure that the cost objectives of the project are not exceeded and that costly omissions that could lead to disputes in the later project life cycle are avoided.

In practice, this ideal situation is not always obtainable. Sometimes, EPC contractors are experienced foreign companies seeking opportunities in developing countries. Such contractors are usually far more advantaged than their Nigerian clients, who understand very little beyond the economic case for the project. Some of the critical EPC contract phases may, therefore, not be thoroughly followed, while others may be entirely skipped thereby increasing the risks at the client's end of the contract.

In this case study, it is intended to determine the phases in which errors and omissions leading to cost overruns were made. 
TABLE 1: PHASES OF AN EPC CONTRACT

\begin{tabular}{ll}
\hline \multicolumn{1}{c}{ Stage } & \multicolumn{1}{c}{ Phase } \\
\hline Pre-project Planning Activities & Business Plan \\
& Product Technical Plan \\
& Facility Scope Plan \\
& Project Execution Plan \\
& Contract Strategy Plan \\
Design Activities & Finalize scope \\
& Detailed cost estimate \\
& Detailed schedule \\
& Detailed design \\
& Prepare work package \\
Materials management & Bulk commodities \\
activities & Fabricated items \\
& Standard Engineered Equipment \\
& Specialised engineered equipment \\
& Field management \\
& Services (GC/Sub-contractors) \\
& Documentation \\
& Field equipment management \\
& Prework \\
Start-up & Execution \\
& Demobilization \\
& Start-up plan \\
& Project Close-out \\
& Commissioning \\
&
\end{tabular}

\section{Cost Overrun In EPC CONTRACTS}

Cost overrun is pervasive in the construction industry. It affects virtual all types of projects whether maintenance or new-build, public or private, complex or simple [20], [21]. Among others, cost overrun in construction projects is blamed on optimism bias or strategic misrepresentation [22]. Optimism bias is over-optimism in which case the estimator ignores or under-weighs the risks associated with the estimate [23]. On the other hand, strategic misrepresentation occurs where the estimator intentionally gives a wrong estimate in order to attain some objective, gain some incentive or reward, such as win a competitive tender [24]. In either case, the contractor is bound by his submission in EPC contracts.

It is the expert contractor's sole responsibility to assess the direct cost, risks and profit for the venture [13]. Incompetent contractors would have been disqualified following the technical bidding process. Hence, claims due to design errors will not be entertained by the client given the underpinning idea, that the contractor's offer and its supporting designs are products of the work of a diligent expert. Secondly, the client obtains a guarantee from the contractor to make good any faults occurring in the project over an agreed postconstruction period of time. In making an offer for the project, therefore, the successful bidder must not be overconfident. He must undertake a painstaking assessment of the risks which the project poses, its local and foreign cost components as well as an acceptable margin.

Although cost overrun can be determined based on the budget estimate, the consultant's estimate prior to tender or the agreed contract sum with the contractor [22], it is better to base that for EPC contracts on the agreed contract sum. In EPC contracts, the contractor's offer is considered as the guaranteed maximum cost by the client. The clients having relied on the contractor's expertise, assumes that the contractor's lump sum cost proposal is inclusive of all foreseeable events that could impact the project.

Cost overrun in this study was, therefore, conceived as the deviation (in percentage) of the final project cost from the agree contract sum. As in other kinds of construction projects, cost overrun in EPC contracts will likely trigger a dispute in such projects.

\section{Research Method}

In this study, the qualitative research methods of ethnography and explorative case study were adopted because depot construction projects are relatively few in Nigeria [26], [27]. The approach involved document analysis and in-depth semi-structured interviews with relevant persons in the project to obtain meanings regarding the cost management of the project [28]. In ethnographic studies, the researcher is immersed in the group he is studying and takes part in the daily activities [29]. Hence, the information obtainable by the ethnographer goes beyond what can be obtained through interviews and includes that which can only be obtained through actual participation in the process [30]. The authors of this work acted as consultants in the project.

In order to determine the cost overruns in the case study, a team of 6 registered quantity surveyors (including the researchers) computed the quantities of the work proposed by the contractor at the inception of the project based on which the contract sum was determined. Secondly, the quantities of work based on the working drawings (produced while the project was on-going) were computed. Site meetings were held in which the project team and contractors identified the reasons for cost overrun in the project. Additionally, private semi-formal interviews were held with the key actors (Table 2) on the project to further elucidate on the issues leading to cost overrun in the project. The interviewees were purposively selected as suggested by Noor [28]. The results of the comparison were analyzed using descriptive statistics and charts where applicable.

\begin{tabular}{|c|c|c|c|c|}
\hline $\mathrm{S} / \mathrm{N}$ & RESPONDENT & PARTY & POSTION & $\begin{array}{c}\begin{array}{c}\text { EXPERIENCE } \\
\text { (years) }\end{array} \\
\end{array}$ \\
\hline 1 & CPE1 & Client & $\begin{array}{c}\text { Project } \\
\text { Engineer }\end{array}$ & 31 \\
\hline 2 & CPE2 & Client & $\begin{array}{l}\text { Project } \\
\text { Engineer }\end{array}$ & 12 \\
\hline 3 & CPE3 & Client & $\begin{array}{c}\text { Project } \\
\text { Engineer }\end{array}$ & 4 \\
\hline 4 & CPE4 & Client & $\begin{array}{c}\text { Client's } \\
\text { team leader }\end{array}$ & 10 \\
\hline 5 & CCE1 & Contractor & $\begin{array}{l}\text { Contractor's } \\
\text { team leader }\end{array}$ & 15 \\
\hline 6 & CCE2 & Contractor & $\begin{array}{l}\text { Quantity } \\
\text { Surveyor }\end{array}$ & 30 \\
\hline 7 & CCE3 & Contractor & $\begin{array}{c}\text { Project } \\
\text { Engineering }\end{array}$ & 20 \\
\hline
\end{tabular}

\section{THE CASE}

The project involved construction of a liquified petroleum gas (LPG) depot in Lagos State Nigeria. Overall, the works involved construction LPG tanks, fire-water tanks, buildings, roads, jetties, sheet piling and other supportive facilities.

The contract was an EPC contract awarded in January 2018 to a foreign EPC contractor. However, the main EPC contractor being a specialist in the development of the mechanical components of a depot suggested a subcontractor for award of the civil engineering components of the project, which was honoured by the client. Both the main and 
subcontractors are foreigners. Award for the civil engineering components was made to the subcontractor for the total sum of $\$ 1,718,777,595.03$ based on conceptual designs presented by the subcontractor. Prior to the conceptual designs, the civil engineering subcontractor sought and obtained funds from the client to carry out independent site investigations based on which the conceptual designs, and subsequently, a bill of quantities was made. The award was based on bespoke conditions of contract. After award of the contract and commencement of the project, the client felt obliged to engage civil and mechanical engineering consultants to monitor the project on his behalf and advise him on the activities of the contractor. This study therefore covers mainly the procurement of the civil engineering components of the depot.

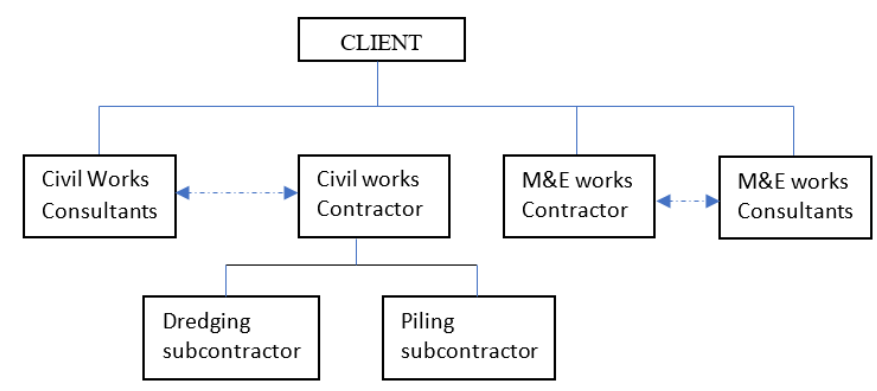

Figure 1: Project Organisation.

\section{RESUlTs AND DisCUSSION}

As a result of the re-measurement of the work, major differences were found between initial costs of sections of the bill of quantities (BoQ) and their actual costs based on the final working drawings. The reasons for these differences were also identified for each section and shown in Table 3. In many instances, the scope of the facilities making up the project were exceeded. The result supports the findings of Rui, et al. [31] that oil and gas projects in Nigeria experience $42 \%$ scope overrun and a $38 \%$ cost overrun. In this case study, the major facilities in the projects collectively exceeded their original cost by $106 \%$. Rui, et al. [31] noted that the range of cost overrun in Nigerian projects is $-12 \%$ to $130 \%$, which implies that the cost variation in the major components of this project tends towards the higher range of cost overrun for the country.

Although the cost of most items of the BoQ were exceeded, the cost of the loading gantry, which was initially overmeasured was not exceeded. The re-measurement resulted in a savings of $\$ 66,956,958.52$ for the client. Largely, this error was owing to the use of floor area in the measurement of the gantry instead of full quantities measurement. As further shown in Chart 1, the highest overall cost overrun occurred in sand filling, which involved dredging sand from the lagoon directly into the site. The increase in the quantities of sand filling was blamed on the high compressibility of the unsuitable materials in the site, which compressed as a result of deposition of the denser sharp sand from the river. It means that the risk of meeting a highly compressible ground on the site was not given adequate attention at the conception stage of the project by the contractor. Ashton and Gidado [32] observed that such risks occur in projects as a result of inadequate site investigation by competent personnel.
Although in this particular project soil investigations were carried out, it seems that the findings of the investigation were not heeded during the design of the facilities. For example, during document analysis, it was revealed that while the soil investigation recommended that pile foundations be used, the conceptual designs of the project had pad foundations, which necessitated major changes in the foundation at the construction stage with attendant cost implications.

The cost overrun also resulted from items in the project which were omitted entirely from the BoQ. In this category included security building, fire pump building, pipe support structure, and air compressor and dryer station. It is noted in literature that poor scope definition adds to the riskiness and complexity of a project [33]. Design and scope changes rank amongst the highest causes of cost overrun in construction projects identified by Creedy, Skitmore, and Wong [34]. It appears that at the detailed design stage, the inclusion of certain structures became inevitable. However, these could not be accommodated within the contingency sum allowed in the project.

In order to identify the cost overrun factors in petroleum products depot projects, key project participants from the parties (Table 1) were interviewed. In addition, exploratory research strategy/document analysis was used to examine the project data for relevant information. Table 4 shows that most of the causes of cost overrun in the petroleum products depot project centre around design and construction activities. This result is in line with Cantarelli et al. [35] to the effect that cost overrun occurs both at the pre-construction and construction stages. This study, however, reveals that most of the cost overrun at the pre-construction stage are related to design activities.

TABLE 4: CAUSES OF THE Cost OVERRUNS AND THE STAGES OF THE PROJECT AFFECTED THE MOST

\begin{tabular}{|c|c|c|}
\hline $\mathrm{S} / \mathrm{N}$ & Cause Of Cost Overrun & Stage Of Origin \\
\hline 1. & Opportunistic behaviour of the client & Project start up \\
\hline 2. & Poorly worded contract agreement & Project start up \\
\hline 3. & Use of a wrong procurement route & Project start up \\
\hline 4. & $\begin{array}{l}\text { Client's inadequate knowledge of EPC } \\
\text { contracts }\end{array}$ & $\begin{array}{l}\text { Pre-project } \\
\text { planning activities }\end{array}$ \\
\hline 5. & Unstable foreign exchange market & $\begin{array}{l}\text { Pre-project } \\
\text { planning activities }\end{array}$ \\
\hline 6. & Late engagement of consultants & $\begin{array}{l}\text { Pre-project } \\
\text { planning activities }\end{array}$ \\
\hline 7. & $\begin{array}{l}\text { Inadequate knowledge of risky aspects } \\
\text { of the project }\end{array}$ & $\begin{array}{l}\text { Pre-project } \\
\text { planning activities }\end{array}$ \\
\hline 8. & Lack of cash flow analysis & Design Activities \\
\hline 9. & Inaccurate survey data & Design Activities \\
\hline 10. & Inadequate geotechnical information & Design Activities \\
\hline 11. & Faulty designs & Design Activities \\
\hline 12. & $\begin{array}{l}\text { Omission of cost items by the } \\
\text { contractor }\end{array}$ & Design Activities \\
\hline 13. & In accurate and unorganized BoQ & Design Activities \\
\hline 14. & $\begin{array}{l}\text { Poor documentation of the } \\
\text { implementation process }\end{array}$ & $\begin{array}{l}\text { Construction } \\
\text { Activities }\end{array}$ \\
\hline 15. & Construction errors & $\begin{array}{l}\text { Construction } \\
\text { Activities }\end{array}$ \\
\hline 16. & $\begin{array}{l}\text { Opportunistic behaviour of the } \\
\text { contractor }\end{array}$ & $\begin{array}{l}\text { Construction } \\
\text { Activities }\end{array}$ \\
\hline 17. & $\begin{array}{l}\text { Commencement of project before } \\
\text { completion of designs }\end{array}$ & $\begin{array}{l}\text { Construction } \\
\text { Activities }\end{array}$ \\
\hline 18. & Unclear/wrong payment stages & $\begin{array}{l}\text { Construction } \\
\text { Activities }\end{array}$ \\
\hline 19. & $\begin{array}{l}\text { Poor communication between the } \\
\text { client and the contractor }\end{array}$ & $\begin{array}{l}\text { Construction } \\
\text { Activities }\end{array}$ \\
\hline 20. & $\begin{array}{l}\text { Delays in the execution of critical work } \\
\text { items }\end{array}$ & $\begin{array}{l}\text { Construction } \\
\text { Activities }\end{array}$ \\
\hline 21. & $\begin{array}{l}\text { Sub-contractors' opportunistic } \\
\text { behaviour }\end{array}$ & $\begin{array}{l}\text { Construction } \\
\text { Activities }\end{array}$ \\
\hline
\end{tabular}


TABLE 3: MAJOR CHANGES IN THE CONTRACT BOQ

\begin{tabular}{|c|c|c|c|c|c|c|c|c|}
\hline $\mathrm{S} / \mathrm{N}$ & $\begin{array}{l}\text { Name of } \\
\text { Structure }\end{array}$ & $\begin{array}{c}\text { Area affected } \\
\text { by change }\end{array}$ & Original design & Current design & Old Cost ( & New Cost ( $)$ & Difference ( & Remarks \\
\hline 1. & $\begin{array}{l}\text { Fire water } \\
\quad \text { tank }\end{array}$ & Base/foundation & $\begin{array}{l}\text { Circumferential } \\
\text { ring wall and } \\
\text { coarse sand } \\
\text { cushion }\end{array}$ & $\begin{array}{c}120 \mathrm{nr} 12 \mathrm{~m} \text { long } \\
\text { bored piles }\end{array}$ & $228,923,076.92$ & $786,658,607.13$ & $557,735,530.21$ & $\begin{array}{l}\text { Cost of the } \\
\text { foundation for the } \\
\text { fire water tank was } \\
\text { not specifically } \\
\text { identified in the } \\
\text { contract BEME. }\end{array}$ \\
\hline 2. & $\begin{array}{l}\text { Block } \\
\text { fence }\end{array}$ & Foundation & Concrete beam & $\begin{array}{c}\text { 86no. } 10 \mathrm{~m} \text { long } \\
\text { driven piles }\end{array}$ & $8,400,000.00$ & $166,833,050.68$ & $158,433,050.68$ & $\begin{array}{l}\text { Piles were } \\
\text { introduced on the } \\
\text { foundation }\end{array}$ \\
\hline 3. & $\begin{array}{l}\text { Security } \\
\text { buildings }\end{array}$ & Foundation & Pad foundation & $\begin{array}{l}\text { 4nr } 15 \mathrm{~m} \text { long } \\
\text { driven piles }\end{array}$ & & & & $\begin{array}{l}\text { The security } \\
\text { buildings were }\end{array}$ \\
\hline 4. & $\begin{array}{l}\text { Security } \\
\text { building }\end{array}$ & $\begin{array}{l}\text { One whole } \\
\text { building }\end{array}$ & $2 \mathrm{nr}$ buildings & $3 n r$ buildings & $19,200,000.00$ & $50,799,857.28$ & $31,599,857.28$ & $\begin{array}{l}\text { previously } \\
\text { enumerated. }\end{array}$ \\
\hline 5. & $\begin{array}{l}\text { Shoreline } \\
\text { protection }\end{array}$ & $\begin{array}{c}\text { Anchorage wall } \\
\text { structure }\end{array}$ & $\begin{array}{l}\text { Ground beam } \\
\text { structure }\end{array}$ & $\begin{array}{l}5.5 \mathrm{~m} \text { long } \\
\text { driven piles }\end{array}$ & $875,083,862.11$ & $1,056,993,443.25$ & $181,909,581.14$ & $\begin{array}{l}\text { Introduction of } \\
\text { anchorage conc } \\
\text { wall with piles }\end{array}$ \\
\hline 6 & Jetty & $\begin{array}{l}\text { Length of jetty } \\
\text { piles }\end{array}$ & $\begin{array}{l}\text { Length of pile } \\
\text { 792m }\end{array}$ & $\begin{array}{l}\text { Increase in the } \\
\text { total length of } \\
\text { jetty piles } \\
2850 \mathrm{~m}\end{array}$ & $194,483,520.00$ & $504,719,378.44$ & $310,235,858.44$ & $\begin{array}{l}\text { Increase in length } \\
\text { of piles as a result } \\
\text { of new soil tests }\end{array}$ \\
\hline 7. & $\begin{array}{l}\text { Fire pump } \\
\text { building }\end{array}$ & $\begin{array}{l}\text { One whole } \\
\text { building }\end{array}$ & None & $\begin{array}{l}8.5 \mathrm{~m} \times 27.5 \mathrm{~m} \\
\text { on } 20 \mathrm{nr} .15 \mathrm{~m} \\
\text { long piles }\end{array}$ & None & $72,408,876.26$ & $72,408,876.26$ & $\begin{array}{c}\text { Omitted from } \\
\text { conceptual designs }\end{array}$ \\
\hline 8. & $\begin{array}{l}\text { Generator } \\
\text { house }\end{array}$ & $\begin{array}{l}\text { Foundation and } \\
\text { Floor area }\end{array}$ & $\begin{array}{l}\text { Pad foundation } \\
\qquad 36 \mathrm{~m} 2\end{array}$ & $\begin{array}{l}\text { 12nr. 15long } \\
\text { driven piles } \\
132 \mathrm{~m} 2\end{array}$ & $3,744,000.00$ & $38,976,903.44$ & $35,232,903.44$ & $\begin{array}{l}\text { Change of } \\
\text { foundation type } \\
\text { from pad to pile } \\
\text { foundation }\end{array}$ \\
\hline 9. & $\begin{array}{c}\text { Pipe } \\
\text { support }\end{array}$ & Entire structure & None & $\begin{array}{l}\text { Conc \& steel } \\
\text { structure }\end{array}$ & None & $32,335,602.37$ & $32,335,602.37$ & $\begin{array}{l}\text { Omitted from the } \\
\text { original BoQ }\end{array}$ \\
\hline 9. & $\begin{array}{l}\text { Loading } \\
\text { service } \\
\text { building }\end{array}$ & $\begin{array}{l}\text { Foundation } \\
\text { Floor area }\end{array}$ & $\begin{array}{l}\text { Pad foundation } \\
\qquad 21 \mathrm{~m} 2\end{array}$ & $\begin{array}{l}\text { 4nr. } 13 \mathrm{~m} \text { long } \\
\text { driven piles } \\
31.2 \mathrm{~m} 2\end{array}$ & $6,720,000.00$ & $16,783,403.23$ & $10,063,403.23$ & $\begin{array}{l}\text { Change of } \\
\text { foundation type } \\
\text { from pad to pile } \\
\text { foundation }\end{array}$ \\
\hline 10 & $\begin{array}{l}\text { LPG pump } \\
\text { and } \\
\text { compressor } \\
\text { station } \\
\text { Air }\end{array}$ & $\begin{array}{l}\text { Foundation } \\
\text { Floor area }\end{array}$ & $\begin{array}{l}\text { Pad foundation } \\
\qquad 245 \mathrm{~m} 2\end{array}$ & $\begin{array}{c}24 \mathrm{nr} .27 \mathrm{~m} \text { long } \\
\text { piles } \\
206 \mathrm{~m} 2\end{array}$ & $25,480,000.00$ & $107,056,697.36$ & $81,576,697.36$ & $\begin{array}{l}\text { Change of } \\
\text { foundation type } \\
\text { from pad to pile } \\
\text { foundation }\end{array}$ \\
\hline 11. & $\begin{array}{l}\text { compressor } \\
\text { and dryer } \\
\text { station }\end{array}$ & Whole building & Whole building & Whole building & None & $25,190,162.86$ & $25,190,162.86$ & $\begin{array}{l}\text { Omitted from the } \\
\text { original BoQ }\end{array}$ \\
\hline 12. & $\begin{array}{l}\text { Loading } \\
\text { bay/gantry }\end{array}$ & $\begin{array}{c}\text { Foundation } \\
\text { Gross floor area }\end{array}$ & $\begin{array}{l}\text { Pad foundation } \\
1224 \mathrm{~m} 2\end{array}$ & $\begin{array}{c}\text { 8no. } 27 \mathrm{~m} \text { long } \\
\text { driven pile } \\
302.4 \mathrm{~m} 2\end{array}$ & $127,296,000.00$ & $60,339,041.48$ & $-66,956,958.52$ & $\begin{array}{l}\text { Reduction in floor } \\
\text { area }\end{array}$ \\
\hline 13. & $\begin{array}{l}\text { Weigh } \\
\text { bridge }\end{array}$ & $\begin{array}{l}\text { Number } \\
\text { Foundation }\end{array}$ & $\begin{array}{c}1 \mathrm{nr} \\
\text { Stone base }\end{array}$ & $\begin{array}{l}2 \mathrm{nr} \\
\text { 8no. } 27 \mathrm{~m} \text { long } \\
\text { piles }\end{array}$ & $16,000,000.00$ & $69,497,838.10$ & $53,497,838.10$ & $\begin{array}{l}\text { Change of } \\
\text { foundation type } \\
\text { from stone base to } \\
\text { pile foundation }\end{array}$ \\
\hline 14. & $\begin{array}{l}\text { Sand } \\
\text { filling }\end{array}$ & Volume & $48,370 \mathrm{~m} 3$ & $125,586.06 \mathrm{~m} 3$ & $213,447,136.00$ & $554,186,165.57$ & $340,739,029.57$ & $\begin{array}{l}\text { Increase in quantity } \\
\text { of sand as a result } \\
\text { of compression of } \\
\text { underlying } \\
\text { materials }\end{array}$ \\
\hline & $\begin{array}{l}\text { TOTAL } \\
\text { COST }\end{array}$ & & & & $1,718,777,595.03$ & $3,542,779,027.45$ & $1,824,001,432.42$ & \\
\hline
\end{tabular}




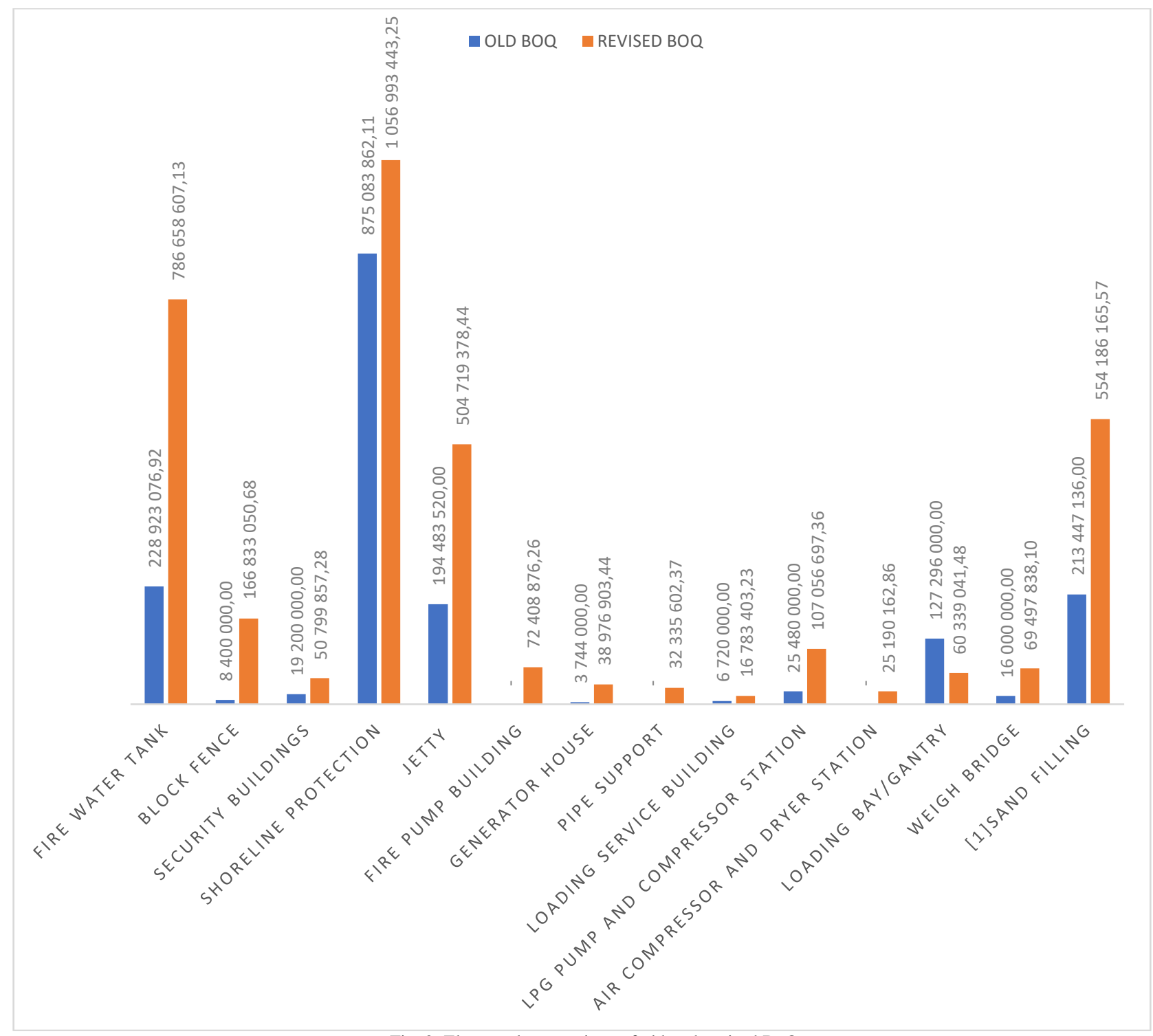

Fig. 2. Elemental comparison of old and revised BoQs.

\section{INTERVIEW RESULTS}

Interviewee CPE1 believed that the contractor was being opportunistic by attempting to use an inferior type of foundation for the project in order to increase his profit. He noted that the contractor was given adequate time and resources to independently study the site, including conducting soil tests to ascertain the appropriate foundation type.

As an EPC contract, the contractor is responsible for his own design. The client should not incur liabilities for the contractor's inability to adequately determine the scope of works and engineer the project. Secondly, the client adequately facilitated the contractor's activities at the early stages to enable him acquire adequate information before submitted a bid for the project.

Interviewee CCE1, however, argued that the client had indicated that he wanted something cheap that could work, and that the type of foundation proposed was good enough to guarantee the integrity of the structures for a 50-year return period.

It is obvious that changes have occurred in this project. And our agreement with the client is that the client will pay for the actual quantities of work completed on site at the rates in the bill of quantities. Now, the client is attempting to renege on this agreement due to the interference of the consultants.

The other interviewees concurred with the views expressed above depending on whether they were on the client's or the contractor's side. Particularly, CPE4 maintained that the contractor should be owing the client if the project were correctly valued. The contract agreement showed that indeed the contractor was to be paid for the actual quantities of work done at the rates in the bill of quantities. Apparently, the parties chose a wrong type of contract for the project since EPC contracts are unsuitable in instances where the client wishes to engage consultants to inspect the contractor's designs and which involves substantial underground work [17]. The clause in the contract which allowed for valuation to be done using the actual quantities achieved on site negates the idea of price certainty, which is a justification for choosing an EPC contract [14]. Although the consultants hardly had significant powers to instruct the contractor (the contract agreement did not recognize the consultants), the consultant's views were taken seriously by the client and determined the client's response to the contractor. When asked the reason why the parties opted for the use of a bespoke contract instead of a standard EPC contract like the FIDIC Silver Book, CPE1 said that the consultants were 
engaged after the parties had entered into the contract and that the contract was drafted by the contractors. Hence, the client was not professionally guided at the time of executing the contract.

\section{CONCLUSION AND RECOMMENDATIONS}

This study investigated cost overrun in an oil and gas depot project in Nigeria. Findings from the study indicate that the cumulative cost overrun of the major items in such projects can be as high as 106\%, particularly, where significant changes in the type of foundation for the various structures occurred. The study reveals that there is substantial risk of cost overrun due to site reclamation by sand filling. It was also found that most cost overrun problems in the project studied emanated from design and construction activities. It shows that problems can arise out of poorly worded contract agreements for EPC contracts, particularly, where the client had not professional advisers to guide his decisions at the early stages.

The implication of this study for policy is that prospective depot owners whose sites are similar to the one in this study should both ensure that adequate soil tests are carried out prior to design of the project, and that the results of the tests are followed by the contractor. Further, the clients can engage professional advisers at the early stages to carefully scrutinize the contractor's conceptual engineering designs to ensure that minimum design standards have been complied with. Unlike the theoretical understanding of EPC contracts, this study has shown that EPC contracts can entail major cost overruns for the clients, especially, where the parties agreed that the contractor will be paid based on the quantities of work completed at the site at the rates shown in contract BoQs. Parties to EPC contracts in Nigeria should show a preference for standard forms of contract rather than bespoke contracts that may not adequately capture their contractual intentions.

\section{REFERENCES}

[1] Odeck, J. (2004). Cost overruns in road construction-what are their sizes and determinants?. Transport policy, 11(1), 43-53.

[2] Flyvbjerg, B., Bruzelius, N., \& Rothengatter, W. (2003). Megaprojects and risk: An anatomy of ambition. Cambridge University Press.

[3] Ali, A. S., \& Kamaruzzaman, S. N. (2010). Cost performance for building construction projects in Klang Valley. Journal of Building Performance, 1(1).

[4] Derakhshanalavijeh, R., \& Teixeira, J. M. C. (2017). Cost overrun in construction projects in developing countries, gas-oil industry of Iran as a case study. Journal of Civil Engineering and Management, 23(1), 125-136.

[5] Stewart, M. D., \& Trierwiler, L. D. (2005). Simulating optimal tank farm design. $P T Q$ magazine $Q, 2,1-5$.

[6] Ehinomen, C., \& Adeleke, A. (2012). An assessment of the distribution of petroleum products in Nigeria. E3 Journal of Business Management and Economics, 3(6), 232-241.

[7] Directorate of Petroleum Resources (DPR) (2018). Depots. Retrieved from https://www.dpr.gov.ng/wp-content/uploads/2018/08/depots.pdf.

[8] Pham, L. H., \& Hadikusumo, H. (2014). Schedule delays in engineering, procurement, and construction petrochemical projects in Vietnam: A qualitative research study. International Journal of Energy Sector Management, 8(1), 3-26.

[9] Pícha, J., Tomek, A., \& Löwitt, H. (2015). Application of EPC contracts in international power projects. Procedia Engineering, 123, 397-404.
[10] Mubin, S., \& Mannan, A. (2013). Innovative Approach to Risk Analysis and Management of Oil and Gas Sector EPC Contracts from a Contractor's Perspective. Journal of Business \& Economics, 5(2), 149 .

[11] PricewaterhouseCoopers (2016) EPC Contracts in the oil and gas sector. Retrieved from https://www.academia.edu/34877653/EPC_Contracts_in_the_oil_and _gas_sector_EPC_Contracts_in_the_oil_and_gas_sector.

[12] Yeo, K. T., \& Ning, J. H. (2002). Integrating supply chain and critical chain concepts in engineer-procure-construct (EPC) projects. International Journal of Project Management, 20(4), $253-$ 262.

[13] Bidua, A. K. (2018). Use of FIDIC 2017 as Standard Form of Contract for EPC Projects in Oil and Gas Industry. Abu Dhabi International Petroleum Exhibition \& Conference. doi:10.2118/193243-ms.

[14] International Federation of Consulting Engineers (FIDIC) (1999). Conditions of contract for EPC/Turnkey Projects. Retrieved from http://www.khabexport.com/upload/Files/fidic-silver-book.pdf.

[15] Schramm, C., Meißner, A., \& Weidinger, G. (2010). Contracting strategies in the oil and gas industry. Pipeline Technology, 2010(Special Edition), 33-36.

[16] Ranjan, M. (2009). EPC: a better approach. Chemical Engineering World, 44(7), 46-49.

[17] International Federation of Consulting Engineers (FIDIC) (2020). EPC/Turnkey Contract 2nd Ed (2017 Silver Book). Retrieved from https://fidic.org/books/epcturnkey-contract-2nd-ed-2017-silver-book.

[18] International Federation of Consulting Engineers (FIDIC) (2019). The FIDIC golden principles ( $1^{\text {st }}$ Edition). Geneva: International Federation of Consulting Engineers https://fidic.org/books/epcturnkey-contract2nd-ed-2017-silver-book.

[19] Back, W. E., \& Moreau, K. A. (2000). Cost and schedule impacts of information management on EPC process. Journal of management in engineering, 16(2), 59-70.

[20] Mahamid, I. (2014). Contractors' perception of risk factors affecting cost overrun in building projects in Palestine. The IES Journal Part A Civil \& Structural Engineering, 7(1), 38-50.

[21] Mahamid, I., \& Bruland, A. (2012). Cost deviation in road construction projects: The case of Palestine. Australasian Journal of Construction Economics and Building, The, 12(1), 58.

[22] Love, P. E., Wang, X., Sing, C. P., \& Tiong, R. L. (2013). Determining the probability of project cost overruns. Journal of Construction Engineering and Management, 139(3), 321-330.

[23] Lovallo, D., \& Kahneman, D. (2003). Delusions of success. Harvard business review, 81(7), 56-63.

[24] Jones, L. R., \& Euske, K. J. (1991). Strategic misrepresentation in budgeting. Journal of Public Administration Research and Theory, 1(4), 437-460.

[25] Welde, M., \& Odeck, J. (2017). Cost escalations in the front-end of projects-empirical evidence from Norwegian road projects. Transport Reviews, 37(5), 612-630.

[26] Yin, R. (1993). Applications of case study research. Beverly Hills, CA: Sage Publishing.

[27] Fisher, I., \& Ziviani, J. (2004). Explanatory case studies: Implications and applications for clinical research. Australian Occupational Therapy Journal, 51(4), 185-191.

[28] Noor, K. B. M. (2008). Case study: A strategic research methodology. American journal of applied sciences, 5(11), 1602-1604.

[29] Grosse, H. (2019). An insider's point of view: autoethnography in the construction industry. Construction Management and Economics, 37(9), 481-498.

[30] Pink, S., Tutt, D., Dainty, A., \& Gibb, A. (2010). Ethnographic methodologies for construction research: knowing, practice and interventions. Building Research \& Information, 38(6), 647-659.

[31] Rui, Z., Cui, K., Wang, X., Chun, J. H., Li, Y., Zhang, Z., ... \& Patil, S. (2018). A comprehensive investigation on performance of oil and gas development in Nigeria: technical and non-technical analyses. Energy, 158, 666-680.

[32] Ashton, P. \& Gidado, K. Bidua (2001, September). Risk associated with inadequate site investigation procedures under design and build procurement systems. In Proceedings of Association of Researchers in Construction Management (ARCOM) conference. http://www.arcom.ac.uk/-docs/proceedings/ar2001-961969_Ashton_and_Gidado.pdf.

[33] Hagan, G., Bower, D., \& Smith, N. (2011). Managing complex projects in multi-project environments. In C. a. L. Egbu, ECW (Chair), Symposium conducted at the meeting of the 27th Annual ARCOM Conference, Bristol, UK. 
[34] Creedy, G. D., Skitmore, M., \& Wong, J. K. (2010). Evaluation of risk factors leading to cost overrun in delivery of highway construction projects. Journal of construction engineering and management, 136(5), 528-537.

[35] Cantarelli, C. C., Molin, E. J., van Wee, B., \& Flyvbjerg, B. (2012). Characteristics of cost overruns for Dutch transport infrastructure projects and the importance of the decision to build and project phases. Transport Policy, 22, 49-56. 